\title{
現代日本の狭長敷地に建つ都市住宅における空辺の構成と冬期の光・熱環境 LIGHT AND THERMAL ENVIRONMENTS NEAR THE WINDOWS OF
CONTEMPORARY JAPANESE HOUSE IN SLENDER SITES DURING WINTER
}

\author{
松元良枝*1, 村田 涼*2, 細川奈未*3 \\ Yoshie MATSUMOTO, Ryo MURATA and Nami HOSOKAWA
}

\begin{abstract}
Regional climate is an important element in architectural design. In particular, passive design that uses natural energy effectively by architectural methods is getting its importance from the viewpoint of environmental problems and energy conservation. The slender sites existing as a typical housing lot offer various requirements for the contemporary urban house. Especially, ambivalent necessities emerge for window such as privacy and view, getting brightness and warmth in winter. This paper aims to clarify characteristics of spatial composition, light environment and thermal environment near the window of contemporary Japanese houses in the slender site during winter.
\end{abstract}

Keywords : Passive design, Spatial composition, Window, Light environment, Thermal environment, House パッシブデザイン，空間構成，空，光環境，熱環境，住宅

\section{1. 序論}

\section{1. 研究の背景と目的}

地域の気候は、建築設計の予条件の重要な要素のひとつである。 とりわけ、光や風などの自然エネルギーを建築的な方法で活用する パッシブデザインは、近年、環境への配慮や省エネルギーの観点か らもその重要性が見直されている。

パッシブデザインの萌芽の例として、V.オルゲーは著書「DESIGN WITH CLIMATE」 ${ }^{1)}$ において、快適な室内気候をつくるには $3 つ$ の段階があるとし、微気候の調整といった屋外環境による手法、建 築による手法、機械設備による手法を挙げ、機械設備のみならず建 築的な工夫の重要性を指摘している。パッシブデザインの建築的な 手法のひとつに、開口部からの昼光の導入や日射熱の取得が挙げら れ、通風、換気の点からも、形状や位置などの空のあり方が重要之 なる ${ }^{2)}$ 。しかしながら、現代の日本の都市では、間口が狭く、奥行 きが長いという特異な立地条件が典型的な敷地として存在しており、 このような周囲に隣家や道路が近接する環境では、プライバシーや 防犯、視線の観点から、自然光や眺望が限定され、採光や視線のコ ントロールを司る空のあり方が規定されやすい。そのため、パッシ ブデザインの定石から導かれる開口部のあり方と、個々の敷地特性 の活用という、時に相反寸る設計条件への対応が必要となり、この ような都市環境に特有の与条件からは、現代の住宅におけるパッシ ブデザインの実践上の課題が多様に現れると考えられる。

特に、冬期における空と日照の関係は、大きな空は明るさや暖か さを得るためには有利である一方、室内からの熱損失の抑制には不
利に働くなど、空による光・熱環境の両義的な性格が顕在化しやす い。そのため空まわりの空間には、立地条件に応じた屋外への開き 方といった構成的な性格に、明るさや暖かさといった室内環境が多 様に関係し、様々な住空間の特徵が見出されると考えられる。そこ で本研究は、現代日本における狭長な敷地に建つ都市住宅を対象と し、リビングなどの主要な室について、空まわりの空間的な特徽と、 シミュレーションソフト注1) により模擬的に再現した冬期の光および 熱環境を重初合わせて検討し、これら空間と環境の関係性の一端を 明らかにすることを目的とする。

\section{2. 既往の研究}

筆者らはこれまで、建築空間と環境のデザインの関係に着目し、 気候図の作成とパッシブデザインへの活用 ${ }^{3)}$ 、現代日本のコートハウ スを対象にした断面構成と光環境の関係 ${ }^{4)}$ 、吉村順三の住宅作品を対 象にした空間構成からみた環境制御の志向性 ${ }^{5)}$ 、寒冷地の住宅におけ る空間形状と温熱環境 ${ }^{6)}$ などにより検討してきた。これらに対して、 これまでなされてきた学術的な研究の内、住空間と地域の気候特性 に着目したものには、沖縄の高温多湿な気候における住宅の空間構

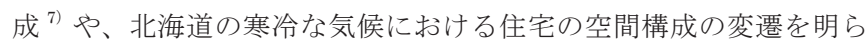
かにしたもの ${ }^{8)}$ 、日本各地の伝統的農家住宅の開口部の形態と立地特 性における体感気候について明らかにしたもの ${ }^{9)}$ が挙げられる。ま た、パッシブデザインの手法の適用や効果については、現代住宅の パッシブデザイン手法の選定要因を事例調査により検討したもの ${ }^{10)} 、$ 熱容量の異なる建物に対する外気導入の影響を検討したもの ${ }^{11)}$ 、蒸 暑地域における都市住宅のパッシブクーリングの効果を検討したも

*1 東京工業大学環境 · 社会理工学院建築学系 博士後期課程

*2 東京工業大学環境・社会理工学院建築学系 准教授・博士(工学)

*3 大成建設(侏) 修士 (工学) 
の ${ }^{12)}$ がある。空間と自然光との関係に着目したものには、多数の建 築事例を対象に空間特性を考慮した採光方式を定性的に体系化した もの ${ }^{13)}$ 、沿海集落の民家の空間構成を光の観点から検討したもの ${ }^{14)}$ がある。また、開口部と住宅の室内環境の関係に着目したものには、 住宅の日当りと空および視環境の実態把握として、都市における住 宅の光に関するアンケート調査を行ったもの ${ }^{15)}$ 、首都圈における夏 期の住宅の空開けに関する調査を示したもの ${ }^{16)}$ がある。これらは建 築空間と環境特性の関係を気候特性や開口部などといった異なる水 準から検討しており、いずれも重要な視座を提供している。

これらの既往の研究に対し、本研究は現代日本の都市環境におけ る典型的な立地条件の一つとして、パッシブデザインを実践する上 での制約条件が多いと考えられる狭長な敷地に着目し、これらの住 宅作品における空間構成と冬期の光・熱環境を検討するものであり、 このような現代日本の都市住宅に特有の空間と環境の複合的な関係 を体系的に比較検討した既往研究は夕られない。そのため本研究の 成果は、現代日本の都市環境に建つ住宅作品における、典型的かつ 特徵的な敷地条件に対するパッシブデザインのあり方からみた空間 的・環境的な特徵に関し有用な知見を与えるものと考える。

尚、本論文は 2018 年度日本建築学会大会学術講演 ${ }^{17)}$ ，18) における 発表の内容に、加筆・修正を加え作成したものである。

\section{3. 研究の方法と概要}

現代日本の住宅地には、相続による分筆などの理由から、道路に 対して開口が狭く細長い形状の敷地が多くみられる注 2)。このような 敷地条件では、建物周りに十分な余白の空間がとりづらく周辺建物 との距離が近くなるなど、自然光を採り込む上で建物の形態が規定 されやすい。そこで本研究では、このような道路に対して間口が狭 く奥行きが長い敷地 (以下、狭長敷地注3) ) に建つ都市住宅における 空まわりの空間構成と冬期の光および熱環境について検討する。そ こで、主要な生活の場として居間を含む空間（以下、主空間注4) に に 着目し、主空間における最も大きな空を主空注5) とし、その近傍の内

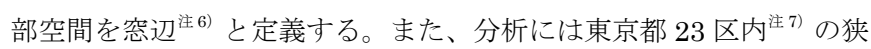
長敷地に建つ戸建て住宅作品の内、分析に十分な資料が得られた 41

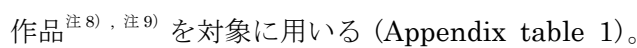

序論に続き 2 章では、住宅が置かれた環境条件に着目し、対象作 品の気候条件を概観した後、さらに主空間の屋外一の開き方として

\begin{tabular}{|l|l|l|}
\hline no.40 CLThouse 荻窪の住宅 & main space \\
主空間 \\
main window \\
主空 \\
site boundary \\
敷地境界線
\end{tabular}

Fig. 1 Analysis example (Capter 2)
空辺の構成を検討する。 3 章では、主空間の空辺を主とした冬期の光 環境を自然光のシミュレーションにより検討する。 4 章では、空辺の 冬期の熱環境を同様に自然室温のシミュレーションにより検討する。 5 章では、前章までに検討した空辺の構成と冬期の光・熱環境の特徵 を重㸚合わせ、これらの空間と環境の関係を検討する。

\section{2. 空辺の構成}

\section{1. 気候条件}

パッシブデザインは建物が立地する場所の特性に大きく関係する。 そこでまず、建物が立地する環境の特徵として、対象作品が位置す る地域の気候条件を整理する。対象作品は、いずれも拡張アメダス 気象データ ${ }^{20)}$ の東京都（東京）に該当し、「地域区分および日射熱 地域区分」 ${ }^{21)}$ では 6 地域であり、比較的温暖な気候にある。また、 年間日射量地域区分 (A 区分) は A3、暖房期日射量地域区分 (H 区分) は H3 と、いずれにおいても比較的日射量が多い地域であり、最も寒 い時期でも外気温は月平均で $0{ }^{\circ} \mathrm{C}$ を回ることはなく、12 月の外気 温は概敉 1 日を通して $6 \sim 12^{\circ} \mathrm{C}$ 程度で推移し、日射量は日中 $375 \mathrm{~W} /$ $\mathrm{m}^{2}\left(1350 \mathrm{~kJ} / \mathrm{m}^{2} \mathrm{~h}\right)$ 程度である注 ${ }^{10)}$

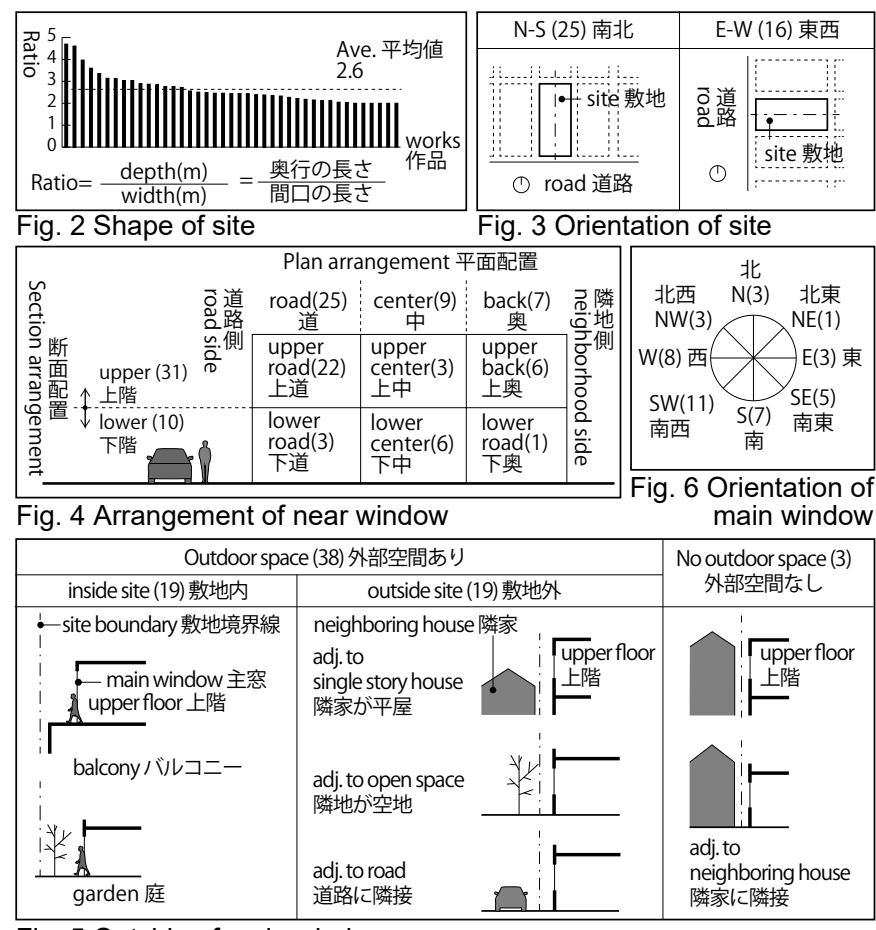

Fig. 5 Outside of main window

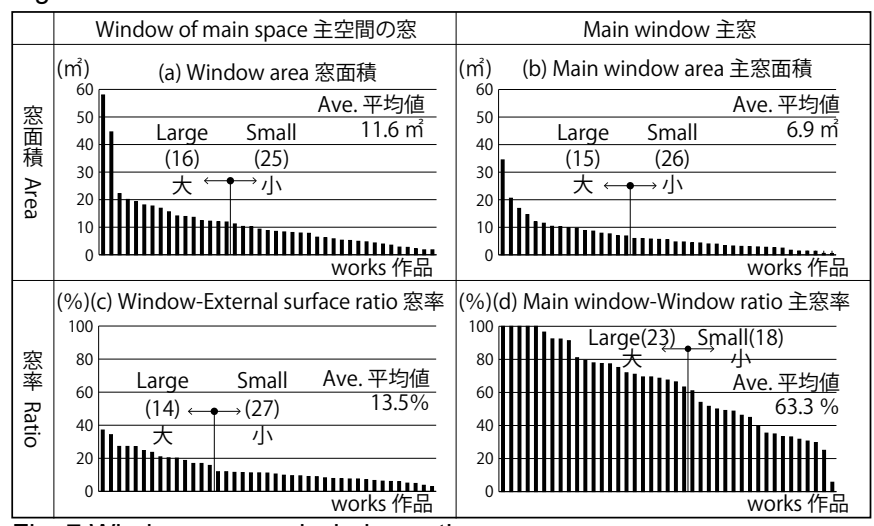

Fig. 7 Window area and window ratio

Fig $3 \sim 7$ Note: "Num" in the figures indicate the number of corresponding works. 図 $3 \sim 7$ 注) 図中の () 内の数は該当する作品数を示す。 


\section{2. 空辺の構成要素}

次に、主空間の屋外への開き方について、空辺の構成要素を検討 する (Fig.1)。

まず、空辺の立地特性として、敷地、建物、空辺の配置について 検討した。敷地の形状 (Fig.2) は、奥行と間口の長さの比が最大で 4.7、 平均は 2.6 である。方位（Fig.3）は、奥行きが南北に長いものが多 い $(25 / 41)$ 。空辺の配置（Fig.4）は、平面的には前面道路側 $(25 / 41)$ が、断面的には上階 $(31 / 41)$ が多い。

さらに、開口による屋外への開き方について、主空の外の広が り（Fig.5）、主空の方位（Fig.6）、主空間の空および主空の面積と割 合（Fig.7）を検討した。空外の広がりは、屋外の空地に開放するも のが大半であり $(38 / 41)$ 、その内、敷地内に庭などの外部空間を設 けるもの、隣家の上空など敷地外の空地に開くものが半数ずつみら れた $(19 / 41 ， 19 / 41)$ 。主空の方位は南西が最も多く $(11 / 41)$ 、南西 を中心とした西、南西、南の三方向が過半数を占める $(26 / 41)$ 。空 の面積と割合は、まず主空間の窓（主空間にあるす心゙ての窓の合計）

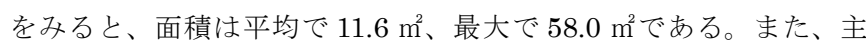
空間における外皮面積に対して空が占める割合（空率）は、平均が $13.5 \%$ 、最大でも $37.1 \%$ であ、空率が $50 \%$ を超え窓が主空間の主 たる外皮となるような事例はみられない。次に、主空の面積をみる と、平均が $6.9 \mathrm{~m}^{2}$ 、最大で $34.5 \mathrm{~m}^{2}$ であ。また、主空間の寸べての 空面積に対して主空が占める割合（主空率）は、平均が $63.3 \%$ であ り、その分布をみると、主空率が $50 \%$ 以上となるものは半数以上あ り $(23 / 41)$ 、そのうち主空のみ（主空率が $100 \%$ ）は 5 件みられた。 一方、 $50 \%$ 未満のものは 3 割程度 $(14 / 41)$ である。

\section{3. 空辺パタン}

前節で検討した空辺の構成要素について、特に敷地環境に対する

Table 1 Near window pattern

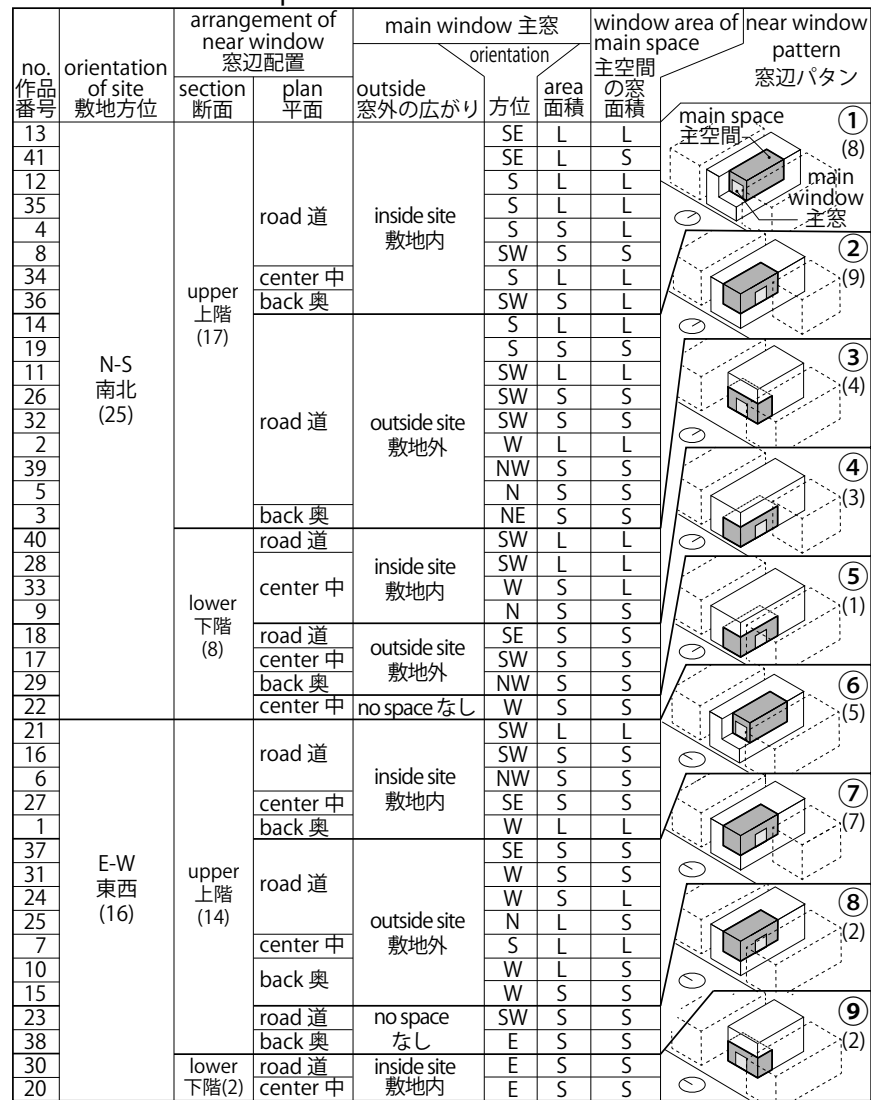

開き方に着目し、敷地の方位、空辺の断面的な配置、主空の外の広 がりの組合せにより (1)〜9)の空辺パタンに分類した（Table1）。南北 に長い敷地に対して上階に空辺が位置し、空外の広がりがある(1)(2) が多く（8/41，9/41)、(1)には敷地の形状と方位の特性を生かすよう に、空と敷地内の外部空間と道路という空地を連放、大きな主空を 南側に向けて開くという傾向が顕著である。(2)も南側に向けて開放 する構成が多いが、敷地外の空地という不定の環境に対して開放す

Table 2 Outline of simulation of light and thermal environments

\begin{tabular}{|c|c|}
\hline Building shape model & 形状モデルの作成 \\
\hline Target house & 対象建物 \\
\hline -Multizone building modeling & 数室モデルとして解析 \\
\hline $\begin{array}{l}\text { - Not include staicase shape and furniture } \\
\text { - Azimth angle/set for each target }\end{array}$ & $\begin{array}{l}\mathrm{e} ・ \text { ・階段の形状や什器は含まない } \\
\text { 方位角 / 事例でとに設定 }\end{array}$ \\
\hline Neighboring buildings and Ground 㕆 & 周辺建物と地表面 \\
\hline - Modeling as shading object without & ・下図の範囲を遮蔽物としてモデル化 \\
\hline reflection(range in below figure) & （日射の反射は含まない） \\
\hline -Albedo(ground reflectance)/0.2 & " /0.2(地表面の日射反射率) \\
\hline Boundary between zones & ゾーンの境界 \\
\hline $\begin{array}{l}\text { - Boundary without surface is set as air } \\
\text { exchange with } 5 \text { times/hour }\end{array}$ & $\begin{array}{l}\text { ・吹抜けなど境界がなくつながっている場合 } \\
\text { は室間換気 } 5 \text { 回 } / \mathrm{h}\end{array}$ \\
\hline Evaluation point & 検討点 \\
\hline $\begin{array}{l}\text { - Near window/1m from main window } \\
\text { - Center/center of gravity of main space } \\
\text { - Height/0.7m above floor }\end{array}$ & $\begin{array}{l}\text { ·空辺 / 平面図における主空から 1m 離れた点 } \\
\text { ·中心 / 平面図における主間の中心 } \\
\text { • 高さ / 床から } 0.7 \mathrm{~m} \text { （悹辺、中心とも） }\end{array}$ \\
\hline Construction & (n) \\
\hline $\begin{array}{l}\text {-Select the spacification of the part } \\
\text { with the largest area of each element } \\
\text { - Set the material composition of each } \\
\text { element } \\
\text {-Solar absorptance/inside and outside } \\
\text { surface }\end{array}$ & $\begin{array}{l}\text { ・部位ごとに面積が最大の部分の仕様を選定 } \\
\text { •各部位（床、壁、天井、屋根、開口部等） } \\
\text { の材料構成を設定 } \\
\text { ・日射吸収率 / 室内外に設定 }\end{array}$ \\
\hline Weather data(Ex. AMeDAS Weather data 200 & 気象データ (拡張アメダス 2000 年版) \\
\hline ·Location/Tokyo(Tokyo) & - 場所 / 東京 \\
\hline - Longitude \& Latitude $/ 35.68^{\circ}, 139.76^{\circ}$ & ・緯度と経度 $/ 35.68^{\circ} ， 139.76^{\circ}$ \\
\hline $\begin{array}{l}\cdot \text { Height } / 6 \mathrm{~m} \\
\cdot \text { Day/Dec.20 }\end{array}$ & $\begin{array}{l}\cdot \text { 高さ } / 6 \mathrm{~m} \\
\cdot \text { 対象日 } / 12 / 20 \text { 比較的日射量が多く外気温が }\end{array}$ \\
\hline $\begin{array}{l}\text { - Ambient temperature/ave.9.4 deg., max. } \\
13.4 \text { deg., min. } 6.5 \text { deg. }\end{array}$ & x. 安定した冬至に近い日 \\
\hline Lighting \& Air conditioning \& Infiltration 照 & 照明・空調・換気 \\
\hline - Lighting device/none & ・照明 /なし \\
\hline - Air conditioning/none & • 空調 / なし \\
\hline - Internal gain/none & - 内部発熱 / なし \\
\hline - Infiltration/0.5 times/hour & $\begin{array}{c}\text { ・換気 } / 0.5 \text { 回 } / \mathrm{h} \\
\text { 周讱建物の于デル化の }\end{array}$ \\
\hline Neighboring buildings models & 周辺建物のモデル化 \\
\hline Building adjacent to site & \\
\hline
\end{tabular}
前面道路の反対側の建物

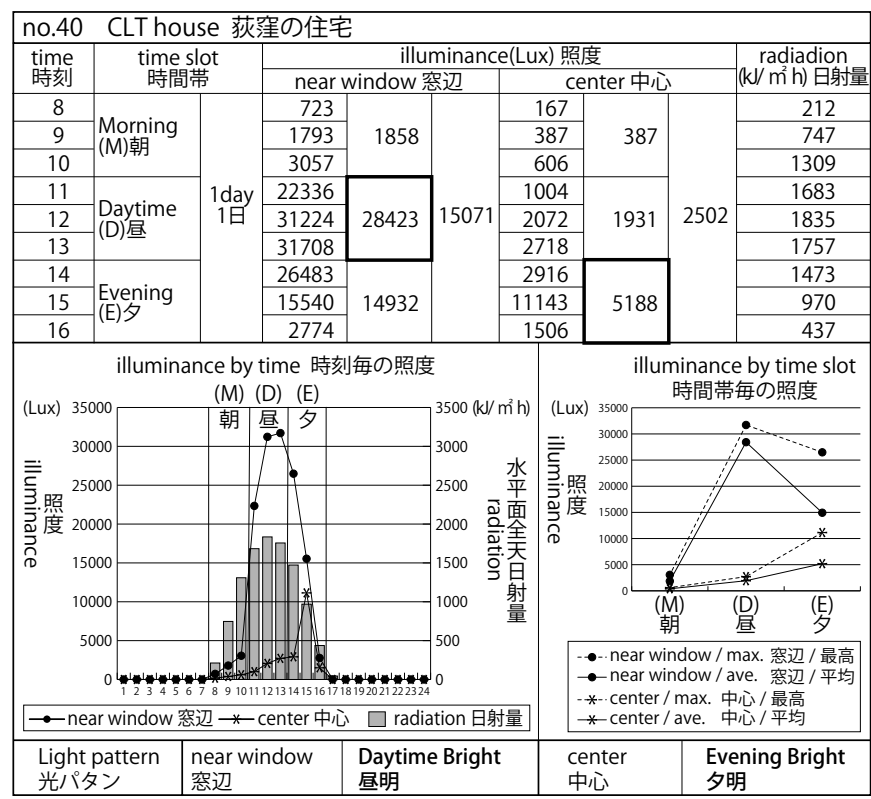

Fig. 8 Analysis example (Capter 3 ) 
るためか、主空の大きさは小さく抑えられる傾向にある。一方、東 西に長い敷地では、同じく上階に空辺が位置し、敷地外に空外の広 がりがある(7)が多い $(7 / 41)$ ここで、主空の方位が冬期の採光・集 熱に有利な南を含む方位（南西、南、南東）に面寸るもの (23/41) について、敷地の方位との関係に着目すると、東西に長い敷地では 4 割に満たない（6/16）のに対し、南北に長い敷地では約 7 割 $(17 / 25)$ に達している。さらに南北に長い敷地の場合、配置は道路側かつ上 階が過半を占めている $(11 / 17)$ 。これらは敷地の狭長さによる方位 と隣地や道路との関係が、開口部のあり方に対して制約条件となる 傾向を示すものと考えられる。

\section{3. 空辺と中心の冬期の光環境}

\section{1. 空辺と中心の照度}

空辺の冬期の光環境について、シミュレーションにより定量的に 検討する (Table2)。立地条件による日射の影響を考慮するため、前 面道路や外構 ${ }^{211)}$ 、軒や庇等を含めた対象建物および周辺建物の形状 をモデル化した。対象建物は住戸全体を多数室モデルとした。方位 や建物の各部位の仕様は事例ごとに個別に設定し 注 12$) 、$ 検討に用いる 対象日は、冬至に近い期間から日射量が比較的多く、気温が数日を 通して安定した日を拡張アメダス気象データ ${ }^{20)}$ を用いて選定した。

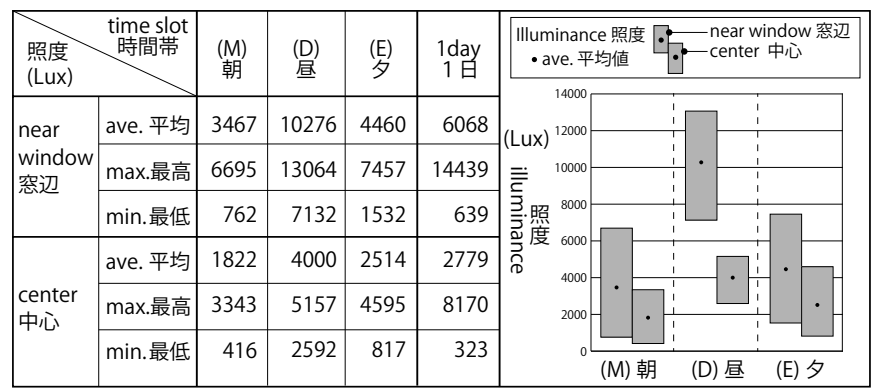

Fig. 9 Average of illuminance at near window and center

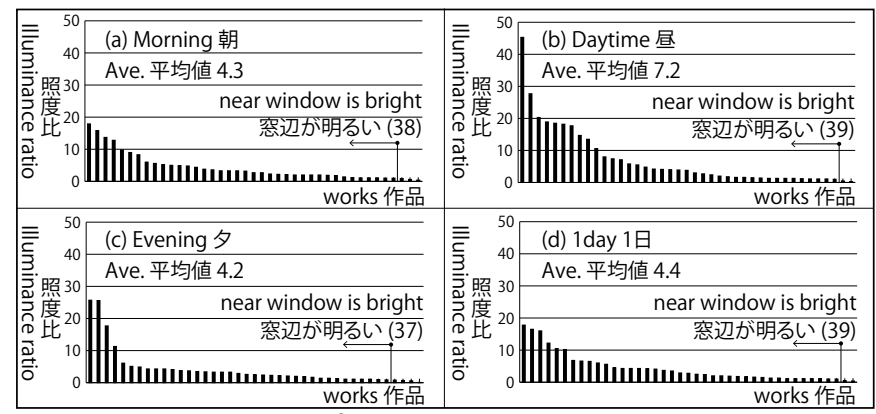

Fig. 10 Illuminance ratio of near window to center

\begin{tabular}{|c|c|c|c|c|c|c|}
\hline \multirow{2}{*}{$\begin{array}{l}\text { Time slot 時間帯 } \\
\text { light pattern } \\
\text { 光パタン }\end{array}$} & \multicolumn{4}{|c|}{ 照度 illuminance(Lux) } & \multirow{2}{*}{\multicolumn{2}{|c|}{$\begin{array}{l}\text { (Lux) }{ }^{15000} \square(\mathrm{MB}) \text { 朝明 } \square(\mathrm{DB}) \text { 昼明 } \square(\mathrm{EB}) \text { 夕明 } \\
{ }^{\prime}\end{array}$}} \\
\hline & $\begin{array}{l}\text { (M) } \\
\text { 朝 }\end{array}$ & 咺) & (E) & $\begin{array}{l}\text { 1day } \\
1 \text { 旦 }\end{array}$ & & \\
\hline $\begin{array}{l}\text { Morning Bright(MB) } \\
\text { 朝明 (6) }\end{array}$ & 4433 & 2209 & 714 & 2452 & 照 9000 & \\
\hline $\begin{array}{l}\text { Daytime Bright(DB) } \\
\text { 昼明 (26) } \\
\end{array}$ & 4228 & 14843 & 5307 & 8126 & 000 & \\
\hline $\begin{array}{l}\text { Evening Bright (EB) } \\
\text { 夕明 (9) }\end{array}$ & 1005 & 2433 & 4132 & 2523 & & (M) 朝 \\
\hline
\end{tabular}

Fig. 11 Light pattern and iluminance of near window

Table 3 Light patterns of near window and center

\begin{tabular}{|l|c|c|c|}
\hline $\begin{array}{l}\text { center near window } \\
\text { 中心 }\end{array}$ & $\begin{array}{c}\text { Morning Bright } \\
\text { 朝明 (6) }\end{array}$ & $\begin{array}{c}\text { Daytime Bright } \\
\text { 昼明 (26) }\end{array}$ & $\begin{array}{c}\text { Evening Bright } \\
\text { 夕明 (9) }\end{array}$ \\
\hline Morning Bright 朝明(6) & 2 & 2 & 0 \\
\hline Daytime Bright 昼明(20) & 3 & 17 & 0 \\
\hline Evening Bright 夕明(15) & 0 & 7 & 10 \\
\hline
\end{tabular}

Fig. 10, 11, 15, Table 3 Note: "Num" in the figures indicate the number of corresponding works. 図 $10,11,15$, 表 3 注) 表中の（）の数字は該当する作品数を示す。
明るさが場所によって顕著に異なることを考慮し、空辺に加え、 主空間の中心注13) (以下、中心) を検討点として設定し、8 時から 16 時の各時刻の照度を算出した (Fig.8)。

まず、時間に応じた明るさの変動の傾向を捉えるため、時間帯ご との照度の平均および最高、最低について全事例における平均値を 用いて検討した (Fig.9)。1 日の最低照度は、空辺が 639Lux、中心 が 323Lux であり、団らんや娛楽にも十分な明るさが概ね得られて いることがわかる注 14)。次に、朝、昼、夕の各時間帯の照度をみると、 空辺および中心ともに、いずれの照度も昼が最も高く、朝が最も低い。 また、時間帯ごとの照度の変化の度合いはいずれも空辺の方が大き く、昼から夕への変化が最も小さい。そこで、このような主空間内 の明るさのむらに着目し、空辺と中心の照度比を時間帯ごとに検討 した（Fig.10）。いずれの時間帯も空辺の方が明るいものが多い。照 度比の平均值は昼が特に大きく、明るさのむらが顕著になる傾向が ある。なお、中心の方が明るくなる場合の多くは、主空間の空に天 空や高空を有する事例（No.17，23，32，33，36）である。

\section{2. 照度の時間変化からみた空辺の光パタン}

次に、1日の中でどの時間帯により多く自然光による明るさを得て いるのかという観点から、各事例について空辺の照度が最高となる 時間帯をもとに光パタンとして分類し、パタンごとに該当事例にお

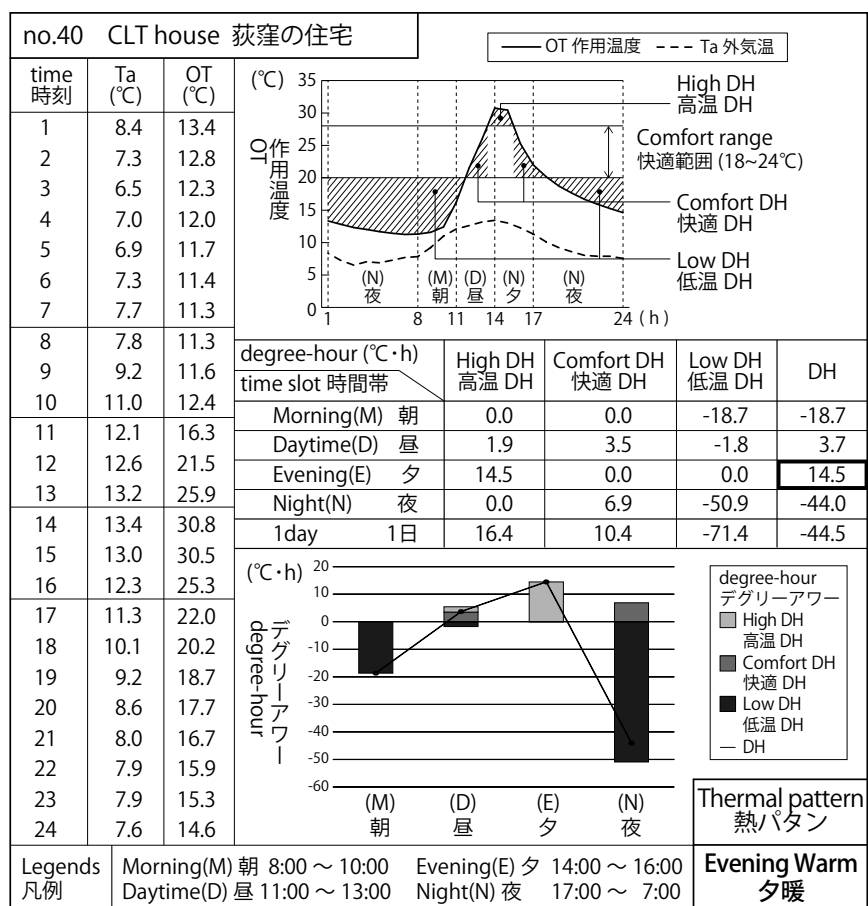

Fig. 12 Analysis example (Capter 4)

\begin{tabular}{|c|c|c|c|c|c|c|c|c|}
\hline \multicolumn{2}{|c|}{ Time slot 時間帯 } & $\begin{array}{l}(\mathrm{M}) \\
\text { 朝 }\end{array}$ & 㕆 & (E) & $\begin{array}{l}\text { (N) } \\
\text { 夜 }\end{array}$ & $\begin{array}{l}\text { 1day } \\
1 \text { 昌 }\end{array}$ & \multirow{8}{*}{$\begin{array}{r}\left.{ }^{\circ} \mathrm{C}\right) \\
18 \\
16 \\
\text { 作 } 14 \\
\text { ○角 } 12 \\
\text { 温 } 10 \\
\text { 度 } \\
6 \\
4 \\
4 \\
2 \\
0 \\
0\end{array}$} & $\begin{array}{l}\text { 一-ave. 平均 }--\max \text {. 最高 } \\
-\rightarrow-\text { min. 最低 } \square \mathrm{Ta} \text { 外気温 }\end{array}$ \\
\hline \multirow{3}{*}{$\begin{array}{l}\mathrm{Ta}\left({ }^{\circ} \mathrm{C}\right) \\
\text { 外気温 }\end{array}$} & ave. 平均 & 9.4 & 12.6 & 12.9 & 8.1 & 9.4 & & \\
\hline & max.最高 & 11.0 & 13.2 & 13.4 & 11.3 & 13.4 & & \\
\hline & min.最低 & 7.8 & 12.1 & 12.3 & 6.5 & 6.5 & & \\
\hline \multirow{4}{*}{$\begin{array}{l}\mathrm{OT}\left({ }^{\circ} \mathrm{C}\right) \\
\text { 作用 } \\
\text { 㿼度 }\end{array}$} & ave. 平均 & 11.0 & 14.8 & 16.3 & 11.6 & 12.5 & & \\
\hline & max.最高 & 12.2 & 16.0 & 17.0 & 14.9 & 17.3 & & \\
\hline & min.最低 & 10.0 & 13.6 & 15.4 & 9.7 & 9.7 & & \\
\hline & DTR 較差 & 2.2 & 2.4 & 1.5 & 5.2 & 7.6 & & \\
\hline
\end{tabular}

DTR: Diurnal Temperature Range (M) 朝 ' $^{\prime}$ (A) 昼 ${ }^{\prime}(E)$ 夕 ${ }^{\prime}(N)$ 夜 Fig. 13 Operative temperature

Fig. 9, 11, 12, 13, 15 Note: In the figures, (M) is Morning, (D) is Daytime, (E) is Evening, and $(\mathrm{N})$ is Night.

図 9，11，12，13，15 注）表中の（M）は朝、(D) は昼、（E) は夕、(N) は夜を示す。 Fig. 12, 13 Note: In the figures, "OT" is operative temperature, "Ta" is ambient temperature.

図 12,13 注) 表中の OT は作用温度、Ta は外気温を示寸。 
ける空辺の照度の時間帯別の平均值をあわせて示した（Fig.11）。昼 の照度が最も高い「昼明」が過半数を占め $(26 / 41)$ 、次に「夕明」 が多い $(9 / 41)$ 。さらに、光パタンごとの該当事例の照度の平均值を みると、「昼明」は 1 日および昼と夕の時間帯で最も高く、特に昼に は他の 2 つのパタンよりも著しく高い明るさを得ている。また、朝 からの照度の上昇は 3 倍以上と著しい。一方、時間の推移に応じた 照度の変化が顕著なのは「朝明」であり、朝から夕にかけて 2 割以 下に減衰している。

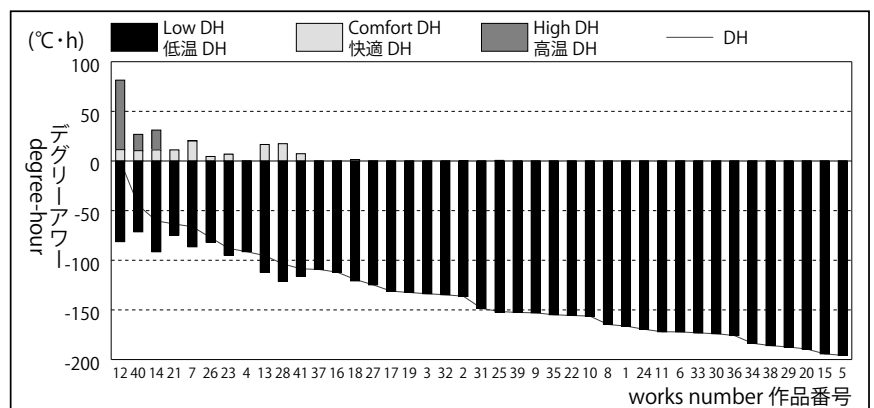

Fig. 14 Distribution of degree-hour (1day)
次に、中心についても同様に分類し、空辺の光パタンとの組合せ を検討した (Table3)。中心も「昼明」が多いが (20/41)、約 3 割は 「夕明」に該当している $(15 / 41)$ 。これにより、空辺と中心の照度は 共に昼に最大となるものが約 4 割（17/41）を占め、ピークの時間帯 がずれる場合は空辺の方が早いものが多い $(3 / 41,7 / 41)$ 。

\section{4. 空辺の冬期の熱環境}

4. 1. 空辺の作用温度とデグリーアワー

空辺の冬期の熱環境について、前章と同様に Table2 の設定により シミュレーションソフトを用いて検討する。空や壁などからの輻射 や、蓄熱によるタイムラグの影響を考慮し、朝、昼、夕、夜の 1 日（24

\begin{tabular}{|c|c|c|c|c|c|c|c|c|c|c|}
\hline Time slot 時間带 & & & $\mathrm{H}\left({ }^{\circ} \mathrm{C} \cdot \mathrm{H}\right.$ & & & \multirow{5}{*}{$\begin{array}{r}\left({ }^{\circ} \mathrm{C} \cdot \mathrm{h}\right) 20 \\
0 \\
-20 \\
0 \\
\text { 모 }-40 \\
-60 \\
-80 \\
-100\end{array}$} & & & & \\
\hline $\begin{array}{l}\text { Thermal Pattern } \\
\text { 熱パタン }\end{array}$ & $\begin{array}{l}\text { (M) } \\
\text { 朝 }\end{array}$ & 㕆 & (罗) & $\begin{array}{l}\text { (N) } \\
\text { 夜 }\end{array}$ & $\begin{array}{l}\text { 1day } \\
1 \text { 白 }\end{array}$ & & & & & \\
\hline $\begin{array}{l}\text { Daytime Warm } \\
\text { 昼暖(6) }\end{array}$ & -15.5 & 1.0 & -4.2 & -95.6 & -114.4 & & & & & \\
\hline $\begin{array}{l}\text { Evening Warm } \\
\text { 夕暖(35) }\end{array}$ & -21.9 & -12.5 & -6.9 & -96.5 & $\mid-137.8$ & & & & & \\
\hline \multicolumn{6}{|c|}{ Thermal Pattern 熱パタン } & & (M) 朝 & (D) 目 & (E) 夕 & (N) 夜 \\
\hline
\end{tabular}

Fig. 15 Thermal pattern and degree-hour

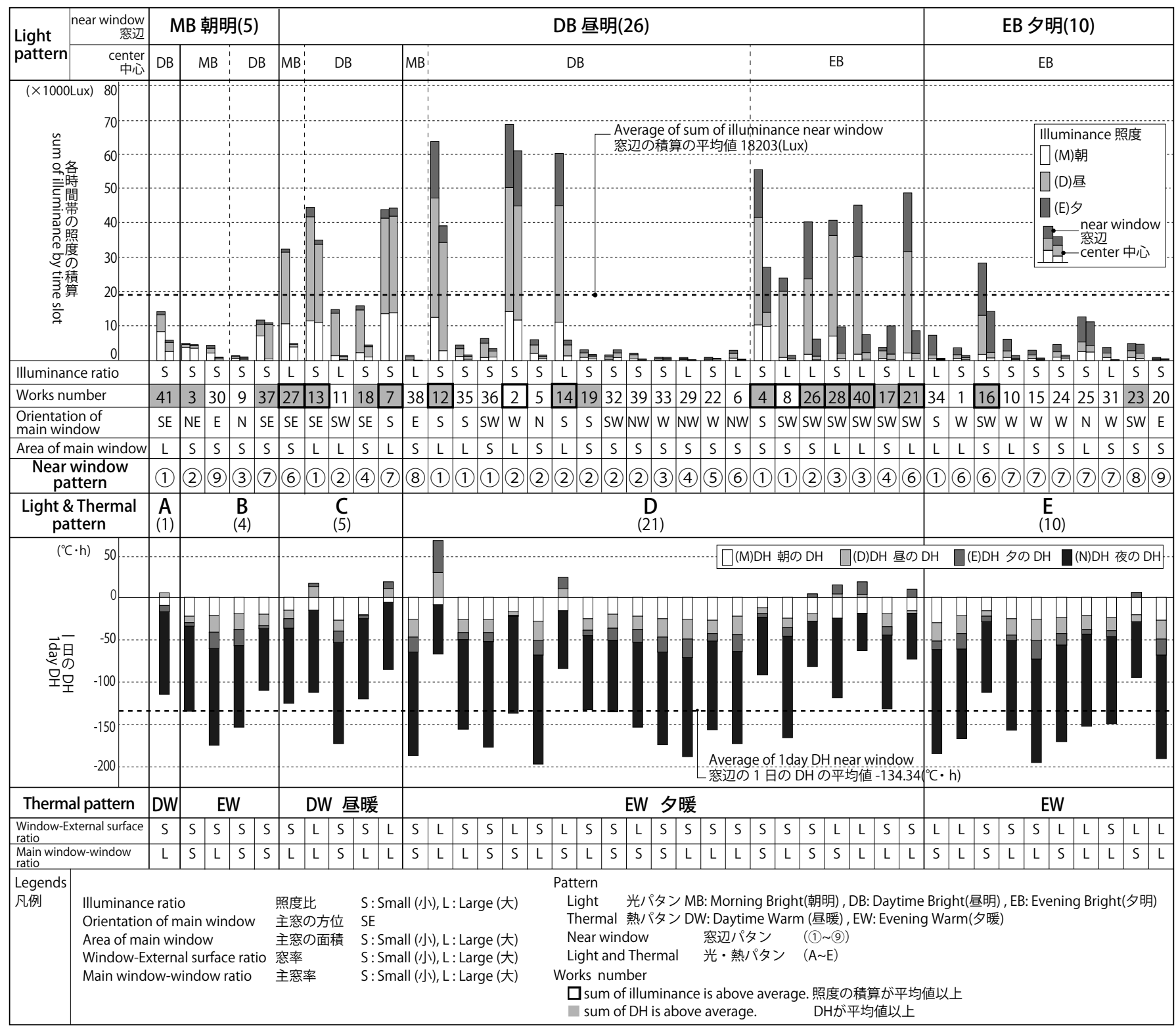

Fig. 16 Light and thermal environments near the window 
時間）の作用温度を算出した（Fig.12）。まず、時間に応じた暖かさ の変動を捉えるため、時間帯ごとの作用温度の平均および最高、最 低について、全事例における平均值を用いて検討した（Fig.13）。作 用温度は 1 日での平均が $12.5^{\circ} \mathrm{C}$ であり、外気温の平均よりも $3.1^{\circ} \mathrm{C}$ 高 い。各時間帯でみると、作用温度はいずれも夕が最も高くなり、較 差は最も小さくなる。

次に、空辺の熱環境が時間に応じて変化する度合いを検討する。 そこで、寒暖の程度を定量的に把握するため、作用温度を快適範囲 注 15)、快適範囲を上回る高温、下回る低温の 3 種類に分けて捉え、作 用温度とこれら各閾值との差の時間積分（以下、デグリーアワー） を、それぞれ高温 $\mathrm{DH}\left(24^{\circ} \mathrm{C}\right.$ を上回る場合の $24^{\circ} \mathrm{C}$ との差の時間積 分）、快適 $\mathrm{DH}$ ( 快適範囲にある場合の $18^{\circ} \mathrm{C}$ との差の時間積分）、低 温 $\mathrm{DH}\left(18^{\circ} \mathrm{C}\right.$ を下回る範囲における $18^{\circ} \mathrm{C}$ との差の負の時間積分 $)$ とし、 これらを総合した DH（＝高温 $\mathrm{DH}+$ 快適 DH + 低温 $\mathrm{DH})$ を指標と した (Fig.14)。総合した DH の值が大きいほど暖かさを得ているこ とを示し、さらに高温、快適、低温の各 DHをあわせることで、時 間変動を加味した寒暖の性状を捉えることができる注 ${ }^{16)}$ 。全事例につ いて各 DH の分布をみると、高温 $\mathrm{DH}$ や快適 DH が発生するものは

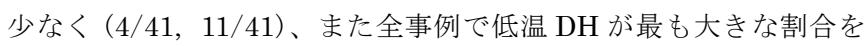
占める。

\section{2. デグリーアワーの時間変化からみた空辺の熱パタン}

次に、自然光の取得により 1 日の中でどの時間帯により多くの暖 かさを得ているのかという観点から、各事例について DH が最大と なる時間帯をもとに熱パタンとして分類し、パタンごとに該当事例 における DH の時間帯別の平均值をあわせて示した（Fig.15）。朝や 夜の時間帯に DH が最大となる事例はみられず、全ての事例が昼ま たは夕に DH が最大となり、この内、夕に DH が最大となる「夕暖」 が大半を占める $(35 / 41)$ 。さらに、熱パタンごとの該当事例につい て時間帯別の DH の平均值をみると、いずれの時間帯も「昼暖」の 方が值が大きく、昼にその差が最大となる。また夕と夜は同程度の 值を示す。

\section{5. 空辺の構成と冬期の光・熱環境}

\section{1. 光・熱パタンと空辺パタンの関係}

前章までの空辺の構成、冬期の光環境および熱環境の特徴を重ね 合わせ、空辺と環境の関係を検討する (Fig.16)。そこでまず、 1 日 の中で自然光による明るさと暖かさを相乗的にどれくらい多く得て いるのかという観点から、空辺の光と熱の各パタンの組合せを検討 し、光・熱パタンとして $\mathrm{A} \sim \mathrm{E}$ が得られた。「昼明」と「夕暖」の 組合せの D が約半数を占める $(21 / 41)$ 。次に、これら光・熱パタン と空辺の構成要素との組合せを検討する。まず敷地の方位との組合 せをみると、南北に長い敷地（（1)～(5)） は D と C の過半数を占めて おり $(18 / 21 、 3 / 5)$ 、昼と夕との関係が強い。東西に長い敷地（ (6)〜

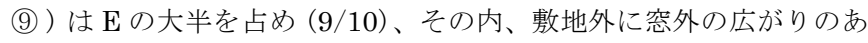
る(7)が多く (5/9)、光と熱の取得のピークは夕方にかけて生じる傾向 にある。次に、空外の広がりのあるものをみると、敷地内 ( (1)(3)(6) (9) ) は約半数が D に該当し (10/21)、南北に長い敷地 ( (1)(3) ) との 組合せが多い $(8 / 10)$ 。ここで、光と熱をより多く取り入れている空 辺に着目する。まず、光について朝、昼、夕の各時間帯の照度を積 算し、その值が平均值以上の 13 件の光・熱パタンをみると、大半が
$\mathrm{D}$ に該当し (9/13)、このうち中心の光パタンは「夕明」が多い (6/9)。 次に、熱について 1 日の DH が平均值以上の 18 件をみると、C と $\mathrm{D}$ に多く(4/18、9/18)、C はその大半を占める $(4 / 5)$ 。さらに、こ れらのうちの光も熱も平均值以上の組合せに着目すると 11 件が該当 し、光・熱パタンは $\mathrm{D}(7) 、 \mathrm{C}(3) 、 \mathrm{E}(1)$ であり、光と熱のピークは 昼以降に限られている。これらの光と熱の場所や時間による変化を みると、空辺と中心の 1 日の照度比が平均值より大きいものが 5 件 あり、約半数に明るさのむらが生じやすい傾向がある。DH の内訳を Fig.14 とあわせて確認すると、低温 DH のみが 3 件、快適 DH を含 むものが 8 件、さらに高温 DH も含むものが 4 件であり、熱の変化 が多様であることがわかる。さらに、これらの空辺の構成要素との 組合せに着目すると、主空の方位は南西を主体 $(5 / 11)$ にすべて南を

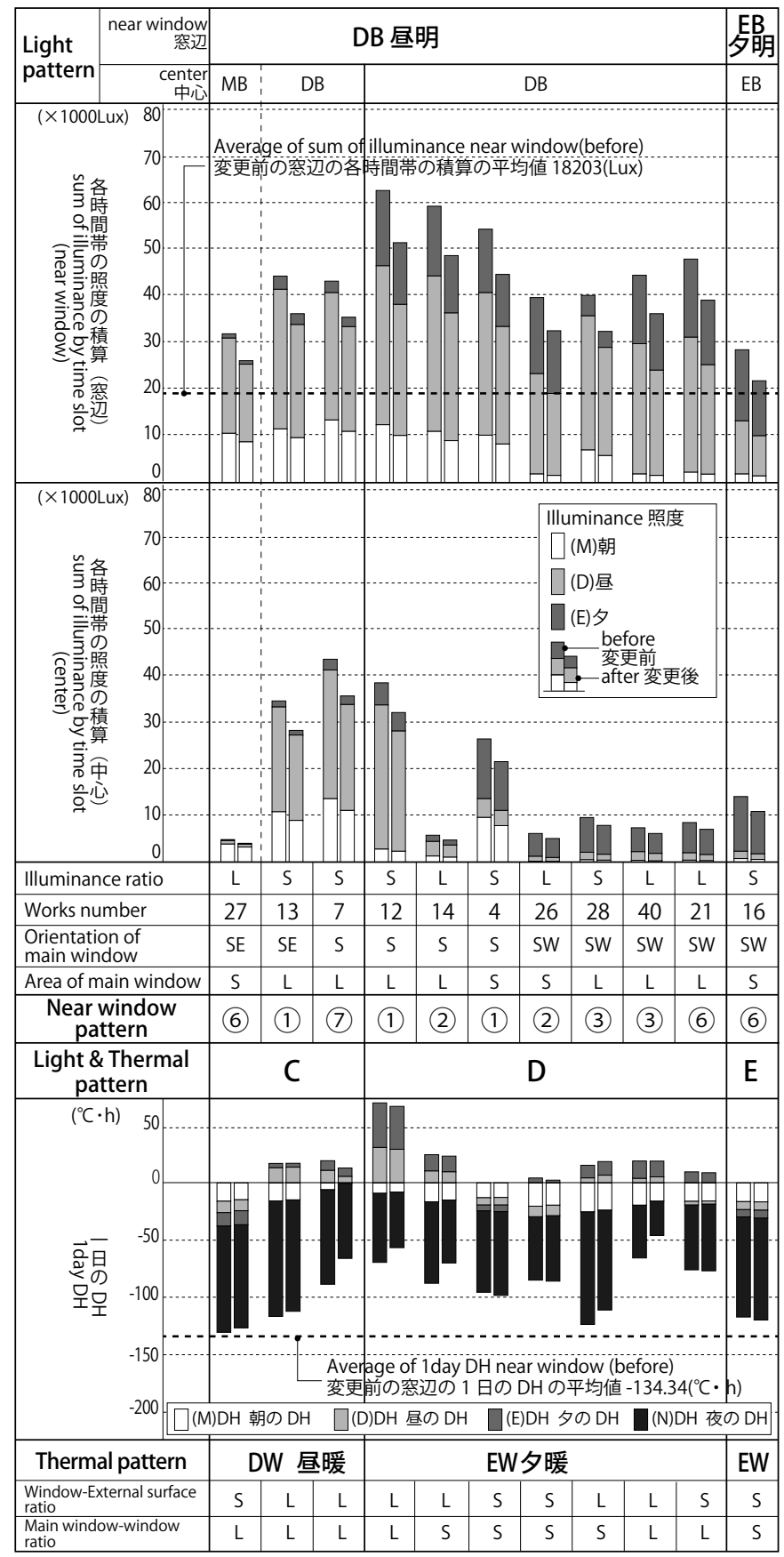

Fig. 17 Effect of improvemenet window's insulation

Fig. 17 Note: The legend is indicated in Fig. 16. 図 17 注）凡例は図 16 に示す。 
含み、空外の広がりは敷地内を主体 $(8 / 11)$ に設けるという条件が共 通し、これらは光も熱もより多く取り入れる上で特に相関の強い要 素であることがわかる。また、主空の面積は大が大半（7/11）であり、 空辺の断面配置は上階を主体 $(9 / 11)$ とし、平面的な配置は道路側 が多く $(8 / 11)$ 、特に上階の断面的配置と敷地内の空外の広がりとの 組合せが多い $(5 / 8)$ 。さらに、敷地の方位との関係をみると、南北 に長い敷地 $(7 / 11)$ では空辺の配置は平面的には道路側が 6 件であり、 このうち断面的には上階が 5 件である。つまり、前面道路を空地と して利用し、街に対して開きながら採光を確保し、中でも上階に配 置することでプライバシーを高めた構成が多いことがわかる。一方、 東西に長い敷地では (4/11)、す心゙て上階である。これらの傾向から、 狭長な敷地が特にその方位に応じて、空辺の配置に対して異なる制 約条件となっていると考えられる。

\section{2. 空の断熱性能の向上の影響}

前節までの検討結果より、熱環境は高温 DH や低温 DH を有する ものが少なく、また、開口部は壁や屋根などの躯体に比べ一般的に 断熱性能が劣ることから、空の性能の向上による熱環境の改善を検 討する。ここでは、空辺の空間性状への影響を抑えながら、熱環境 を改善する方法として、枠およびガラスの断熱性能の変更に着目す る。そこで、光と熱ともに平均值以上であった 11 件を対象に、これ らの空の断熱性能の変更を検討する (Fig.17)。

いずれの事例も、枠とガラスの組合せは金属製熱遮断構造＋複層 ガラス辛 17) であるため、これらを木製十低放射複層ガラスに変更し、 変更前後での照度とDH を比較した。ここで、複層ガラスから低放 射複層ガラスに変更することにより、断熱性能は上がるが可視光透 過率や日射熱取得率は小さくなり、光と熱の間でトレードオフが発 生する。そのため、いずれの事例も照度は空辺、中心ともに低下し、 その割合は空辺、中心ともに最大で $23 \%$ 程度、平均で $18 \%$ 減である。 しかし、大半 $(7 / 11)$ で DH が増大し、開口部の断熱性能の向上によ る温熱環境の効果がみられた。特に、No.7の事例では、DH が一日 を通して上昇し、熱パタンが「昼暖」から「夕暖」となり光・熱パ タンが C から D に変化している。一方、DH が低下した 4 件 (No.4, $26 ， 21 ， 16)$ は光・熱パタンが $\mathrm{D} 、 \mathrm{E}$ であり、主空の方位は南西が多 く $(3 / 4)$ 、空率、主空率ともに小さいものが多い $(3 / 4)$ 。こで構造・ 構法に着目すると、No.4、16 は RC 外断熱であり、ガラスの変更に より室内への日射熱が減少し、躯体への蓄熱量も低下したことで、 室温や作用温度の上昇が抑えられたためと考えられる。

6. 結

本研究では、現代日本の狭長敷地に建つ住宅作品を対象に、パッ シブデザインの観点から冬期における窓辺の空間と光・熱環境の関 係性を検討した。

2 章の空辺の構成に関する分析では、対象作品の気候条件を概観し、 さらに主空間の敷地環境に対する開き方に着目し、空辺の構成要素 の組合せを検討した。敷地が南北方向に長い場合は、主空の断面配 置が上階か敷地の内や外に空外の広がりを設ける構成が多く、敷地 が東西方向に長い場合は、上階で、敷地外に空外の広がりを設ける ものが多いなどの特徵を明らかにした。

3 章の冬期の光環境に関する分析では、空辺と中心の光環境につい てシミュレーションにより検討した。窓辺の照度は昼が最も高くな るものが多く、中心は昼に加え夕も一定数みられること、場所ごと
の明るさのむらは特に昼に顕著なことなどの特徴を明らかにした。

4 章の冬期の熱環境に関する分析では、空辺の熱環境についてシ ミュレーションにより検討した。作用温度のデグリーアワーを指標 とし、夕に $\mathrm{DH}$ が最大となるものが特に多いこと、快適 $\mathrm{DH}$ や高温 $\mathrm{DH}$ を有する事例は少ないことなどの特徵を明らかにした。

5 章では、前章までの空辺の構成と光・熱環境を重初合わせて検 討した。光と熱の両方をより多く取り入れている空辺には、主空の 方位は南を含み、敷地内に空外の広がりを設けるという強い相関関 係がみられ、また、敷地の方位が空辺の配置に対して制約条件とな る傾向がみられること、空の断熱性能を向上すると、すべての事例 で照度は空辺、中心ともに低下するものの、概ね DH は大きくなり、 熱環境は改善されるが、空の大きさや方位、躯体の構造・構法によっ ては異なる性状を示すなどの特徵を明らかにした。

以上、本研究で明らかにした空辺の空間と光・熱環境の関係には、 現代日本の都市住宅に特有の空と環境のせめぎあいの特徴の一端を 見出すことができ、現代における日本のパッシブデザインのあり方 を思考する上で有用な知見となるものと考える。また、本研究では 冬期について検討したが、夏期の室内環境亡日射遮蔽や通風などは、 本稿とは異なる視点からの空辺の空間と環境特性に関する考察が可 能であり、今後の研究により明らかにしていく予定である。

\section{参考文献}

1) Victor Olgyay: DESIGN WITH CLIMATE, Princeton University Press, 2015 (first published in 1963)

2) SHOKOKUSHA:Passive design method dictionary in architecture for natural energy use newly-revised edition, SHOKOKUSHA Publishing, pp.36-39, 42-49, 76-79, 2000.7

彰国社編：自然エネルギー利用のためのパッシブ建築設計手法事典. 新訂版, 彰国社, pp.36-39, 42-49, 76-79, 2000.7

3) Matsumoto Yoshie, Kodama Yuichiro, Takemasa Koji, Murata Ryo, Kaneko Naoshi, Miyaoka Futoshi: Development and application of passive climate chart, Journal of Environmental Engineering (Transactions of AIJ), Vol.82, No.737, pp.653-662, 2017.7

松元良枝、小玉祐一郎、武政孝治、村田涼、金子尚志、宮岡大：パッシブ気 候図の作成とパッシブデザインへの活用，日本建築学会環境系論文集，第82 巻, 第737号, pp.653-662, 2017.7

4) Murata Ryo, Kaneko Asumi: Sectional composition and light environment in winter of the courtyard and adjacent rooms in contemporary Japanese courtyard houses, Journal of Architecture and Planning (Transactions of AIJ), Vol.79, No.700, pp.1321-1327, 2014.6 村田涼、金子明日美:現代日本のコートハウスにおける中庭まわりの断面構 成と冬期の光環境, 日本建築学会計画系論文集, 第79巻, 第700号, pp.13211327, 2014.6

5) Matsumoto Yoshie, Murata Ryo, Hasegawa Yui and Fujiwara Kisa: The intentionality towards environmental design in terms of spatial composition in Junzo YOSHIMURA's houses, Journal of Architecture and Planning (Transactions of AIJ), Vol.83, No.745, pp.397-404, 2018.3

松元良枝, 村田涼, 長谷川由依, 藤原紀沙：吉村順三の住宅作品における主 空間の構成からみた環境制御の志向性, 日本建築学会計画系論文集, 第83巻, 第745号, pp.397-404, 2018.3

6) Fujiwara Kisa, Murata Ryo, Yuasa Kazuhiro, Yasuda Koichi: The relationship between form and thermal environment on main room models of contemporary houses in Hokkaido, Journal of Architecture and Planning (Transactions of AIJ), Vol.80, No.708, pp.315-322, 2015.2

藤原紀沙，村田涼，湯淺和博，安田幸一：北海道の現代住宅における主空間 の形状と温熱環境の関係性, 日本建築学会計画系論文集, 第80巻, 第708号, pp.315-322, 2015.2

7) Tanoue Kenichi, Ogura Nobuyuki, Fukushima Shunsuke: Spatial 
characteristics of the pilotis-type detached housing analyzing by housing needs and dwelling usage, Journal of Architecture, Planning and Environmental Engineering (Transactions of AIJ), Vol.64, No.522, pp.147-153, 1999.08

田上健一，小倉暢之，福島駿介：住要求および居住実態からみたピロティ型 戸建住宅の空間特性, 日本建築学会計画系論文集, 第64巻, 第522号, pp.147153, 1999.8

8) Ohgaki Naoaki, Taniguchi Naohiro: Study on growing process of "the plan based on living room" in Hokkaido -Concerning the development of technique protected against the cold-, Journal of Architecture and Planning (Transactions of AIJ), Vol.70, No.590, pp.131-136, 2005.4

大垣直明，谷口尚弘：北海道における『居間中心型』プランの発展過程に関 する研究 防寒技術の発展との関係を中心として, 日本建築学会計画系論文 集, 第70巻, 第590号, pp.131-136, 2005.4

9) Uno Yuji, Horikoshi Tetsumi: Dimensions and configurations of opening in traditional varnacular houses and bioclimate in Japan, Journal of Architecture, Planning and Environmental Engineering (Transactions of AIJ), Vol.65, No.538, pp.37-43, 2000.12

宇野勇治，堀越哲美：伝統的農家住宅の開口部形態・位置と立地地域にお ける体感気候, 日本建築学会計画系論文集, 第65巻, 第538号, pp.37-43, 2000.12

10) Suzuki Masaaki, Ichikawa Takanori:A study on passive design techniques and the selection factors of modern houses, Journal of Environmental Engineering (Transactions of AIJ), Vol.74, No.642, pp.1001-1008, 2009.8

鈴木聖明，市川尚紀：現代住宅のパッシブ設計手法とその選定要因に関する 事例調査研究, 日本建築学会環境系論文集, 第74巻, 第642号, pp.1001-1008, 2009.8

11) Miyaoka Futoshi, Kodama Yuichiro, Takemasa Koji, Hasui Chikako: Difference of ventilation mode on passive cooling effect, Journal of Environmental Engineering (Transactions of AIJ), Vol.72, No.618, pp.37-43, 2007.8

宮岡大，小玉祐一郎，武政孝治，蓮井睦子：外気導入モードの違いがパッシ ブクーリング効果に及ぼす影響，日本建築学会環境系論文集，第 72 巻，第 618 号, pp.37-43, 2007.8

12) Sugiyama Susumu, Yasufuku Satoshi, Kubota Tetsu, Toe Doris Hooi Chyee; Effectiveness of energy-saving renovation techniques through passive cooling for urban houses in hot-humid climate of Malaysia, Journal of Environmental Engineering (Transactions of AIJ), Vol.80, No.714, pp. 673-683, 2015.8

杉山奨, 安福悟志，久保田徹，Toe Doris Hooi Chyee：高温多湿気候下のマ レーシアの都市住宅を対象としたパッシブクーリングによる省エネルギー改 修効果の検討，日本建築学会環境系論文集，第80巻，第714号，pp.673-683, 2015.8

13) Koizumi Takashi, Suzuki Nobuhiro: Effects of the sunlight on spatial orders and their causes in architectural spaces, Journal of Architecture, Planning and Environmental Engineering (Transactions of AIJ), Vol.64, No.516, pp.153-160, 1999.2

小泉隆，鈴木信宏：建築空間における空間秩序的太陽光効果とそれらの要因, 日本建築学会計画系論文集, 第64巻, 第516号, pp.153-160, 1999.02

14) Ito Masaaki, Kuroyanagi Akio, Nakamura Shigeki: A study on the spatial composition of the coastal villeges caught it from light as an environment element -About the formation of the villege, the house and the living habitude as settlements Part3-, Journal of Architecture, Planning and Environmental Engineering (Transactions of AIJ), Vol.66, No.539, pp.103-110, 2001.01

伊藤昌明，畔柳昭雄，中村茂樹：自然環境要素としての光から捉えた沿海集 落の空間構成に関する研究 生活環境としての集落・民家・生活習慣の成立 についてその3, 日本建築学会計画系論文集, 第66巻, 第539号, pp.103-110, 2001.01

15) Sato Masato, Nakayama Kazumi, Yoshida Keishi, Miyatani Rie: A study on actual conditions of sunlight, windows and visual environments of houses:A survey by questionnaires concerning lighting of houses in urban areas Part 1, Journal of Environmental Engineering (Transactions of AIJ), Vol.75, No.655, pp.799-806, 2010.9 佐藤仁人，中山和美，吉田圭志，宮谷梨江：住宅の日当りと空および視環境
の実態 都市における住宅の照明に関するアンケート調査 その 1 , 日本建 築学会環境系論文集，第75巻，第655号, pp.799-806, 2010.9

16) Tsubota Yuji, Nakayama Kazumi, Hazama Yoshikazu: A research on window opening/closing in dwellings in summer: Attitude and behavior survey in the Tokyo metropolitan area through internet, Journal of Environmental Engineering (Transactions of AIJ), Vol.77, No.676, pp.515-521, 2012.6

坪田祐二，中山和美，間純一：夏期の住宅における空の開放に関寸る調査研 究 首都圏におけるインターネットアンケート調査による空の開放の意識と 実際の空の開放，日本建築学会環境系論文集，第77巻，第676号，pp.515-521， 2012.6

17) Matsumoto Yoshie, Hosokawa Nami, Murata Ryo: Light and thermal environments near the windows of contemporary Japanese house in slender sites during winter(1), Summaries of Technical Papers of Annual Meeting, Architectural Institute of Japan, History and Theory of Architecture, pp.447-448, 2018.7

松元良枝，細川奈未，村田涼：現代日本の狭長敷地に建つ都市住宅における 空辺と冬期の光 ・ 熱環境 (1), 日本建築学会大会学術講演梗概集 建築歴史 · 意匠, pp. 447-448, 2018.7

18) Hosokawa Nami, Matsumoto Yoshie, Murata Ryo: Light and thermal environments near the windows of contemporary Japanese house in slender sites during winter(2), Summaries of Technical Papers of Annual Meeting, Architectural Institute of Japan, History and Theory of Architecture, pp.449-450, 2018.7

細川奈未，松元良枝，村田涼：現代日本の狭長敷地に建つ都市住宅における 空辺と冬期の光 - 熱環境 $(2)$, 日本建築学会大会学術講演梗概集 建築歴史 · 意匠, pp. 449-450, 2018.7

19) Kitayama Koh, Tsukamoto Yoshiharu, Nishizawa Ryue: Tokyo Metabolizing, TOTO Publishing, p.40, 2010.7

北山恒，塚本由晴，西沢立衛：トウキョウ・メタボライジング，TOTO出版， p.40, 2010.7

20) Architectural Institute of Japan: Expanded AMeDAS Weather Data 1981-2000, Kagoshima TLO, 2005.8

社団法人日本建築学会：拡張アメダス気象データ 1981-2000, 鹿児島TLO, 2005.8

21) Building Research Institute: Technical information on the evaluation of energy consumption performance in compliance with the Energy Conservation Standard, 2016.4

国立研究開発法人建築研究所 : 平成 28 年省エネルギー基準に準拠したエネル ギー消費性能の評価に関する技術情報（住宅），2.2.11-2章 日射に関する地 域の区分と日射量等, 2016.4

22) SHASEJ: SHASE-G1001-2012 Heating Air-Conditioning Sanitary engineers' Program for Experience and Education, SHASEJ, pp.40-41, 2012.10

公益社団法人空気調和・衛生工学会 : 試して学ぶ熱負荷HASPEE〜新最大熱 負荷計算法～，丸善出版, pp.40-41, 2012.10

23) Tanaka Shunroku, Takeda hitoshi, Iwata toshie, Tsuchiya Takao: Building environmental engineering, INOUESHOIN, p.182, 2013.3 田中俊六, 武田仁, 岩田利枝, 土屋喬雄, 寺尾道仁 : 最新建築環境工学改訂2 版, 井上書院, p.182, 2013.3

24) Kawashima Yoshikatsu: Thermal environment of housing for elderly people, Rikogakusha Publishing, 1994.6 川島美勝:高齢者の住宅熱環境, 理工学社, 1994.6

\section{注}

注1）非定常の多数室温熱環境シミュレーションソフトTRNSYS18を熱環境 の検討に、TRNSYS18に統合された昼光シミュレーションソフトDaySIM、 Radianceを光環境の検討に使用した。なお、TRNSYS18は、国土交通省の 特別評価方法認定 (年間暖冷房負荷の計算方法を用いて評価する方法) を取 得している(認定番号329)。

注2）参考文献19）に、東京において世代を経て土地が分割されて宅地の狭長 化が進む変遷が示されている。

注3）敷地の奥行と間口の長さの比が 2 以上、短辺のみが接道しているものを対 象とする。また、旗竿敷地の場合は、旗部分の道路側の幅員を間口とした。

注4）図面中に居間やダイニングなどと表記されたひとつながりの空間。1つの 作品に複数みられる場合は居間を含む空間を対象とした。

注5）同形状の空がある場合、居間の近傍のものを主空とした。 
注6）位置は、主空の中心から室内側に $1 \mathrm{~m} 、 \mathrm{FL}+0.7 \mathrm{~m}$ とした。

注7）同一の気候特性の下、宅地の狭長化が広くみられる地域として、東京都 23区内を対象範囲として選定した。

注8）本研究では、日本における現代の建築ジャーナリズムの中で代表的なも のと思われる「新建築 住宅特集」誌の 2000 年から 2017 年に掲載された、本 研究で定義する狭長敷地に建つ新築一戸建て専用住宅の内、東京都23区内に あり、敷地面積が $100 \mathrm{~m}^{2}$ 以下、地下階が 1 以上、地上階が 3 以下のものの中か ら、分析に十分な資料が得られた 41 件を対象としている。

注9）対象事例の選定において、建物の階数や敷地の面積には制限を設けず、 また敷地が長辺で接道するものも含むという条件では112件が確認され、さ らに狭小で間口も狭いという条件を加味し、狭長敷地に建つ都市住宅として の条件をより明確に備えた 41 件を対象として選定した。

注10）参考文献3）東京の気候図が示されている。

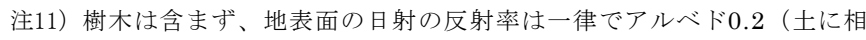
当）として設定した。

注12）断熱性等の各部位の仕様は資料中の矩計図やデータシート等をもとに個 別に設定し、材料は参考文献22）、日射吸収率は参考文献23）より設定した。 なお、気密性は一律で換気回数 0.5 回 $/ \mathrm{h}$ とした。

注13）平面図から部分的な凹凸は無視し、不整形は長方形に近似し設定した。

注14）JIS Z9110において、住宅の居間の推奨照度は、手芸、裁縫は1000Lux, 読書は500Lux, 団らん、娛楽は200Luxとされている。

注15）参考文献24）評価のための基準值として、高齢者・身障者に配慮した住 宅熱環境評価基準值 (一般人)では、冬期における居間・食堂の温度は黒球温 で $21 \pm 3^{\circ} \mathrm{C}$ されている。黒球温と作用温度は概称等しいものとし、その温 度をもとに $18^{\circ} \mathrm{C} \sim 24^{\circ} \mathrm{C}$ を快適範囲と定義した。

注16）本稿で定義するデグリーアワーは、基準温度との差を用いた指標である 暖房デグリーデーや冷房デグリーデーの方法を援用しているが、冬期に自然 光による熱をいかに多く得ているのかという観点から、快適範囲においては 下限值である $18^{\circ} \mathrm{C} と の$ 差を加味し、快適DHを設定している。

注17）比較前の開口部の性能は熱貫流率 $3.49 \mathrm{~W} / \mathrm{m}^{2} \mathrm{~K}$ 、日射熱取得率 0.79 , 可 視光透過率 0.82 、比較後の性能は、熱貫流率 $1.89 \mathrm{~W} / \mathrm{m}^{2} \mathrm{~K}$, 日射熱取得率 0.63 可視光透過率 0.72 とした。
Appendix table 1 Works list

\begin{tabular}{|c|c|c|c|c|}
\hline No. & Year & Name & (in Japanese) & Structure \\
\hline 1 & $2001 / 1$ & House in Setagayakamimachi & 世田谷上町の家 & $\mathrm{RC}, \mathrm{W}$ \\
\hline 2 & $2002 / 4$ & Tokyo tokyo & Tokyo トーキョー & $\mathrm{RC}, \mathrm{S}$ \\
\hline 3 & $2002 / 4$ & Box House 49 & 箱の家 -49 & W \\
\hline 4 & $2002 / 5$ & House in Hatanodai & 旗の台の家 & $\mathrm{RC}$ \\
\hline 5 & $2003 / 3$ & Natural weage & ナチュラルウェッジ & $\mathrm{S}, \mathrm{RC}$ \\
\hline 6 & $2003 / 4$ & House in Yoga & 用賀の家 & $\mathrm{RC}$ \\
\hline 7 & $2004 / 4$ & House in Tairamachi & 平町の家 & $\mathrm{RC}, \mathrm{S}$ \\
\hline 8 & $2006 / 11$ & TRICOT & TRICOT & $\mathrm{RC}, \mathrm{S}$ \\
\hline 9 & $2007 / 3$ & House tower & ハウス・タワー & $\mathrm{RC}$ \\
\hline 10 & $2007 / 4$ & Natural Stick & ナチュラルスティック & $\mathrm{RC}$ \\
\hline 11 & $2007 / 12$ & LC-SH12 & 八丁堀・櫻庵 LC-SH12 & $\mathrm{s}$ \\
\hline 12 & $2007 / 12$ & Oval Panel House & Oval Panel House & W \\
\hline 13 & $2007 / 12$ & House in Otsuka & 大塚の家 & $\mathrm{S}, \mathrm{RC}$ \\
\hline 14 & $2007 / 12$ & Iron House & 鉄の家 & $\mathrm{s}$ \\
\hline 15 & $2008 / 6$ & KHB & KHB & $\mathrm{W}, \mathrm{RC}, \mathrm{S}$ \\
\hline 16 & $2009 / 5$ & House in Higashiyama & 東山の家 & $\mathrm{RC}$ \\
\hline 17 & $2010 / 1$ & Platinum House & シロガネの家 & W \\
\hline 18 & $2010 / 7$ & Tower Machiya & タワーまちや & $\mathrm{s}$ \\
\hline 19 & $2010 / 7$ & YK & YK & $\mathrm{S}, \mathrm{RC}$ \\
\hline 20 & $2011 / 2$ & Split Machiya & スプリットまちや & $\mathrm{RC}, \mathrm{W}$ \\
\hline 21 & $2011 / 10$ & House in Yoyogiuehara & 代々木上原の家 & $\mathrm{W}, \mathrm{RC}$ \\
\hline 22 & 2012/1 & gate & gate & W \\
\hline 23 & $2012 / 3$ & Natural StripIV & ナチュラルストリップIV & $\mathrm{S}$ \\
\hline 24 & $2012 / 3$ & House in Motoasakusa & 元浅草の住宅 & $\mathrm{S}$ \\
\hline 25 & $2012 / 5$ & 43base & 43base & $\mathrm{s}$ \\
\hline 26 & $2012 / 5$ & BW3 & BW3 & W \\
\hline 27 & $2012 / 12$ & GALA House & GALA HOUSE & $\mathrm{RC}$ \\
\hline 28 & $2013 / 2$ & House in Nishi-ogikubo & 西荻窪の家 & $\mathrm{S}, \mathrm{W}$ \\
\hline 29 & $2013 / 4$ & MARUSANKAKUSHIKAKUNOIE & マルルサンカクシカクイエ & W \\
\hline 30 & $2013 / 11$ & House in Kyuden & 給田の家 & W \\
\hline 31 & $2014 / 4$ & 1.8M width House & $1.8 \mathrm{~m}$ 幅の家 & $\mathrm{s}$ \\
\hline 32 & $2014 / 6$ & House in Torigoe & 鳥越の住宅 & $\mathrm{s}$ \\
\hline 33 & $2015 / 1$ & Roji Machiya & ロジまちや & W \\
\hline 34 & $2016 / 4$ & Familiar House & ファミリアハウス & $\mathrm{S}$ \\
\hline 35 & $2016 / 4$ & Hirairi in Magome & 馬込の平入 & W \\
\hline 36 & $2016 / 4$ & House in Kamimeguro & 上目黒の住宅 & W \\
\hline 37 & $2016 / 4$ & House in Hamadayama & 浜田山の住宅 & W \\
\hline 38 & $2016 / 6$ & Microclimate House & 微気候の家 & $\mathrm{s}$ \\
\hline 39 & $2017 / 5$ & TRANS & TRANS & $\mathrm{RC}$ \\
\hline 40 & $2017 / 6$ & CLT House & 荻窪の住宅 & $\mathrm{W}(\mathrm{CLT})$ \\
\hline 41 & 2017/11 & elling & 日本橋 $\sigma$ & \\
\hline
\end{tabular}

Appendix table 1 Note: "Year" in the table indicates the year and month of publication of the magazine of the corresponding work.

別表 1 注）表中の year は該当寸る作品の雑誌掍載年月を示す 


\title{
LIGHT AND THERMAL ENVIRONMENTS NEAR THE WINDOWS OF CONTEMPORARY JAPANESE HOUSE IN SLENDER SITES DURING WINTER
}

\author{
Yoshie MATSUMOTO ${ }^{* 1}$, Ryo MURATA*2 and Nami HOSOKAWA*3 \\ ${ }^{* 1}$ Doctoral Student, Dept. of Architecture, Tokyo Institute of Technology \\ ${ }^{*}$ Assoc. Prof., Dept. of Architecture, Tokyo Institute of Technology, Dr.Eng. \\ ${ }^{* 3}$ Taisei Corporation, M.Eng.
}

Introduction:

Regional climate is an important element in architectural design. In particular, passive design that uses natural energy effectively by architectural methods is getting its importance from the viewpoint of environmental problems and energy conservation. Window is one of fundamental elements for passive design methods such as daylighting and cross ventilation. However, the slender sites with narrow frontage and deep depth exist as a typical housing lot in contemporary urban area in Japan. These conditions might restrict the design direction of these houses, especially for window, because the locational factors cause limitations for their arrangements while various necessities for the urban house, such as keeping privacy, safety and view, are required. Hence, it is necessary for their design to respond to both requirements, one is from the passive design solutions and the other is from each site's specific conditions. It could be considered that various characteristics of practices for passive design in contemporary houses emerge throughout their investigations. Particularly, ambivalent characteristics between light and thermal environment near the large window in winter which has advantage to get much sunlight but disadvantage for keeping warm could be found. Therefore, this paper aims to clarify characteristics of spatial composition, light environment and thermal environment near the window of contemporary Japanese houses in the slender site during winter.

Methods:

First, spatial composition of near the window is examined besides the overview about climatic condition. Then, characteristics of the main space and its windows are analyzed as seen from the way to open to surroundings.

Second, light and thermal environments of the main space in a winter day are analyzed by simulations. Light environment is examined by illuminance near the window and the center while thermal environment near the window is examined by operative temperature with considering variations in a day.

Third, relationships of spatial composition, light and thermal environments are analyzed.

Results:

1) In both the long north-south site and the long east-west site, the main space and near the window tend to be located on the upper floor and opened to the outside site.

2) The illuminance near the window is highest mostly in the daytime while the center place tends to be highest also in the evening. The unevenness of illuminance between these places also increases mostly in the daytime. In the analysis of thermal environment near the window, the degree-hour (DH) is used to indicate fluctuation of operative temperature. Many cases show the highest amount of DH in the evening while the Comfort DH and the High DH rarely appear.

3) The composite analysis of space and environment shows correlative characteristics among the cases which get much the light and heat of the sun. It indicates that the main window facing south with outdoor space inside site is superior. Further investigation regarding improvement of thermal insulation performance of the window indicates a tendency of a trade-off between brightness and warmth. The DH generally increases and thermal environment is improved in most cases though it differs depending on the size of window and the structural property. 